The Limb-Deficient Child 

THE CHILD AMPUTEE PROSTHETICS PROJECT / DEPARTMENT OF PEDIATRICS SCHOOL OF MEDICINE / UNIVERSITY OF CALIFORNIA, LOS ANGELES

\section{The Limb-Deficient Child}

\section{Edited by BERTON BLAKESLEE}

Photography by MARY LOUISE HISTON 
University of California Press, Berkeley and Los Angeles Cambridge University Press, London, England (c) 1963 by The Regents of the University of California Library of Congress Catalog Card No. 63-16210

Printed in the United States of America 